\title{
Community-based mangrove forest management action in Rangsang region, district of Kepulauan Meranti, Riau
}

\begin{abstract}
One of the coastal ecosystems that have experienced a high level of degradation due to its utilization pattern which tends not to pay attention to its sustainability aspects is the mangrove forest in Rangsang District, Meranti Islands Regency, and Riau, Indonesia. Seeing the symptoms of mangrove forest destruction for various purposes, it is necessary to manage mangrove forests sustainably. To be able to carry out sustainable management of mangrove forests, management efforts are needed ber of strategic value and right. Management of community-based marine resources is one management strategy that can improve efficiency and fairness in the utilization and management of natural resources. The research aims to identify and analyze the condition of mangrove forests, reviewing mangrove forest management, and the development of community-based mangrove forest in the district of stimuli. The approach used in this study is an analytical descriptive approach with survey methods. This research was conducted in Rangsang sub-district, Meranti Islands regency, Riau.
\end{abstract}

The results showed that the mangrove vegetation found included 7 species from 3 families, namely Avicenniaceae (Avicennia alba and Avicennia marina), Rhizophoraceae (Rhizophora mucronata, Rhizophora apiculata, Rhizophora stylosa, and Bruguiera gymnorrhiza) families, and Sonneratiaceae family (Sonneratia alba), with the value of diversity index $\left(\mathrm{H}^{\circ}\right.$ ) of mangrove vegetation in Rangsang sub-district at each station ranged from 0.91 to 1.69 and the environmental parameters of mangrove vegetation in Rangsang sub-district were obtained from clay sand, sandy clay and sandy clay; Soil $\mathrm{pH}$ ranges from 6.6-7.1; temperatures range from $29-31^{\circ} \mathrm{C}$; salinity ranges from $27-31 \mathrm{ppt}$; and organic matter content between 1.09-7.65. At the very least, there are three factors of decision making on community participation in mangrove forest management, namely management factors, knowledge factors and attitude factors. Meanwhile, mangrove forest management carried out by the community in Rangsang District in the form of rehabilitation, care and supervision. Therefore, in an effort to manage community-based mangrove forests active community participation is required by taking into account management factors, knowledge factors and attitude factors.

Keywords: Rangsang District, mangrove Forest, factor analysis, community based mangrove ecosystem management
Volume 3 Issue 6 - 2018

\author{
Abu Hanifah,' Kamaruddin Eddiwan ${ }^{2}$ \\ 'Environmental Agency of Kepulauan Meranti Regency, Indonesia \\ ${ }^{2}$ Faculty of Fisheries and Marine Science, University of Riau, \\ Indonesia \\ Correspondence: Kamaruddin Eddiwan, Aquatic Biology \\ Laboratory. Faculty of Fisheries and Marine Affairs, Riau \\ University, Binawidya Campus Jln HR Soebrantas Km I2.5 Kec. \\ Tampan, Kota Pekanbaru, Riau, 28293, Indonesia, \\ Email kamaruddinaddiwan@gmail.com
}

Received: August 27, 2018 | Published: November 23, 2018

\section{Introduction}

Rangsang sub-district is one of the coastal areas on the east coast of Sumatra (Figure 1), which has a vast mangrove forest population. The coastal area is a transitional area between land and ocean ecosystems that have high biological productivity. ${ }^{1}$ The contribution of nutrients from the land through the flow of the river and the flow of surface water when it rains, as well as the growth and development of various natural ecosystems such as mangrove forests, coral reefs, sea grass beds and estuaries, causing the coastal area, is very fertile. ${ }^{2}$ With this potential and easy accessibility, region coastal areas are used for various purposes.

Ecosystem, Mishra ${ }^{3}$ said that coastal resources play an important role in supporting regional and national economic development to increase foreign exchange earnings, employment, and population income. These coastal resources have a comparative advantage because they are available in large and diverse quantities and can be used with relatively cheap exploitation costs, so as to create competitive bidding capacity. ${ }^{4}$ However, behind this potential; the existence of resources is often threatened due to development that is not environmentally sound.
In the last decade, development activities in coastal areas have been quite rapid, both for fisheries, settlements, mining, and tourism and so on. The rapid development of this and coupled with a high level of population density, has caused various environmental problems in several coastal areas of Indonesia. These problems include the degradation of natural ecosystems. One of the coastal ecosystems that experience a high level of degradation due to its utilization pattern which tends not to pay attention to its sustainability aspect is mangrove forests. The area of Indonesian mangrove forest according to the Ministry of Forestry in 1982 was around 4.25 million ha. The results of the National Forest Inventory conducted by the same Department stated that the area of Indonesian mangrove forests in 1996 was only 3.53 million ha. Thus, within 14 years Indonesia has lost around 700 thousand hectares of mangrove forests and this has happened almost throughout the Indonesian archipelago.

Finn $\mathrm{M},{ }^{5}$ mangrove forests are one of the coastal resources that play an important role in development. Mangrove area actually has a very important role for humans and animals that live in it or around it, even for living things that only stay for a while. Various functions and benefits of mangrove forests for humans and the 
surrounding environment are generally known. Mangroves, magal, mangroves, coastal forests, and fire-fire forests are the names for coastal plant communities that have special adaptations. ${ }^{6}$ Mangroves play an important role in marine life. Ecologically, mangrove forests can guarantee the maintenance of the physical environment, such as waves, wind and seawater intrusion, as well as places breeding for various types of marine life such as fish, shrimp, crabs, clams, snails, and other types of animals. In addition, mangrove forests are also a habitat for wildlife such as monkeys, snakes, beavers, monitor lizards and birds. Badola $\mathrm{R}^{7}$ said that the importance of mangrove forests from the socio-economic aspects can be proven by community activities using mangrove forests to search for wood and also natural attractions. Besides that, it is also the life and source of sustenance for fishermen and coastal farmers who depend on natural resources from mangrove forests.

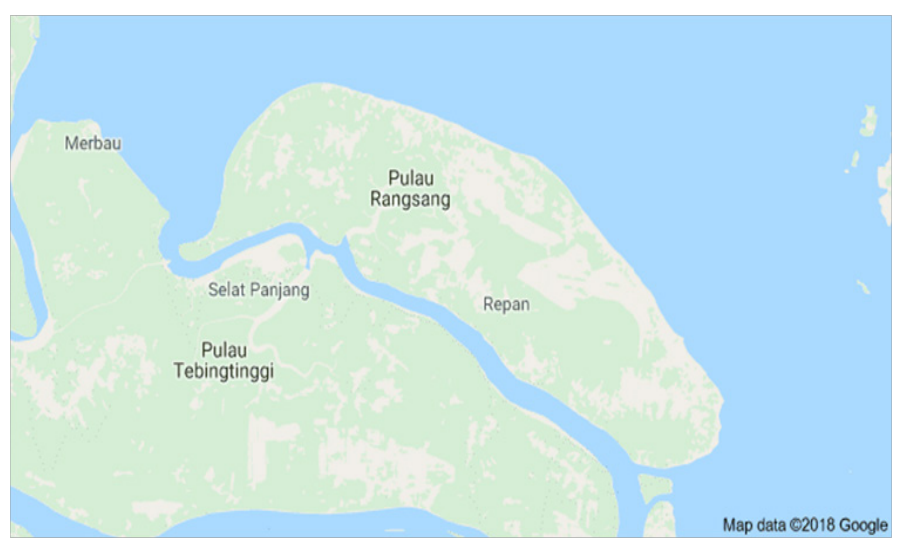

Figure I Map of Rangsang Island, Kepulauan Meranti district, Riau province, Indonesia.

Damage to mangrove forest ecosystems on the coast of Java, for example, progresses more rapidly along with the increase in economic efforts that are more directed to coastal areas. ${ }^{8}$ Changes made to coastal areas have sacrificed thousands of hectares of mangrove areas so that many mangrove areas are no longer functioning properly. This damage is largely due to human pressure in utilizing and clearing mangroves for aquaculture, industry, agriculture, settlements and recreation, as well as a small part due to natural disasters (floods, droughts and tsunami storms) and pest attacks. ${ }^{9}$

Seeing the symptoms of mangrove forest destruction for various purposes, it is necessary to manage mangrove forests sustainably. ${ }^{10}$ To be able to carry out sustainable management of mangrove forests, knowledge of the strategic value of the existence of mangrove forests is needed which is beneficial to the surrounding community. ${ }^{11}$ Schwerdtner et al. ${ }^{12}$ said that management of community-based marine resources is one of the management strategies that can improve efficiency and fairness in the utilization and management of natural resources. Besides this strategy can bring positive ecological and social effects. Management natural resources, especially local community-based marine resources, are very appropriate to be applied in Indonesia, in addition to its positive effects as well as considering that local communities in Indonesia have strong attachments to their regions so that the management will endeavor for the good of the region and not vice versa. Departing from the assumption that the sea is not merely an ecological system, but also a social system. ${ }^{13}$ Therefore, the development of marine resources by paying attention to their unique social-ecological system becomes important. The strength of local institutions on the coast is a maritime nation pillar. If they are empowered, their local rules can complement the formal legal power, they can become effective marine supervisors, become local fisheries managers because they are supported by local knowledge (traditional ecological knowledge), as well as driving the growth of the coastal economy. ${ }^{14}$

With Thus involving goodness' people in the development and management of mangrove forest ecosystems are a strategic step and the right, in addition to the above considerations, and also considering the extensive amount of small islands in Indonesia are difficult to control by the authorities, because of limitations personnel and equipment. In addition, with the capital of the management of community-based mangrove forest ecosystem management as well as fostering the public's sense of the meaning of the protection of marine resources which is very meaningful to the lives of people today and future generations. ${ }^{15}$ Without community participation in every government policy, the goal of establishing the policy is difficult to achieve. ${ }^{16}$ Therefore, to prevent more severe damage to marine resources in Indonesia efforts to develop community participation in the implementation and supervision of these policies must always be carried out.

Based on the background description, the research problem is limited by the formulation of the problem:

1) How the condition of the mangrove forest area in Rangsang District?

2) How do people participate and classify the factors of community participation in the management of mangrove forests in Rangsang District?

3) How to manage mangrove forests in Rangsang District?

4) How is the development of community-based mangrove forest management?

To answer the formulation of the problem above, the research objectives were established:

a) To identify and analyze the condition of mangrove forest areas in Rangsang District

b) To classify or map the factors of community participation in the management of mangrove forests in Rangsang District

c) Assessing mangrove forest management in Rangsang District

d) Putting community-based forest management aside.

\section{Research methods}

The approach used in this study is an analytical descriptive approach with survey methods. As we know that the descriptive method is designed to gather information about real conditions now (in progress). Our main goal in using this method is to describe the nature of a transient condition when the research is conducted and examine the causes of a particular symptom (Travers, 1978 in Sevilla, 1993).

This research was conducted in the coastal area of the Madura Strait of East Java, precisely in the coastal area of Rangsang Subdistrict, Meranti Islands Regency. Determination of the sample in this study was carried out using purposive sampling technique. Sampling where the collection of elements included in the sample is done intentionally, with a note that the sample is representative or represents the population. In research regarding community 
participation in efforts to manage mangrove forests in the Kepulauan Meranti Regency, a sample of respondents was taken based on sample linkages with research objects. Sampling must be based on characteristics, characteristics or certain characteristics which are the main characteristics of the population, in this case, the users of resources, stakeholders and coastal communities of Rangsang subdistrict which are in the mangrove forest ecosystem. The basis of the consideration that caused the researcher to choose the sample of respondents in the coastal community of Rangsang Sub district because the community inhabited the coast and daily activities were directly related to the mangrove area in Rangsang District.

\section{Method of collecting data}

Based on the research objectives and the research method used, the data collected in this study consisted of biophysical data and community social data, obtained from primary and secondary data. Primary data is collected through direct observation/analysis in the field and survey, namely direct interviews with the community and literature studies.

\section{Data analysis}

\section{Analysis of mangrove forest vegetation}

According to Bengen, ${ }^{17}$ data on species, a number of stands and tree diameters that have been recorded, are further processed to obtain species density, species frequency, the area of closure area, and species importance. As for Species density (Di) is the number of species stands i in a unit area: $D i=n i / A$. where, di. is the density of species $i$, this is the total number of individuals from species $i$ and A is the total area of the sample area (total plot area/ plot).

Relative Species Density (RDi) is the ratio between the number of individual species $\mathrm{i}(\mathrm{ni})$ and the total number of individuals of all species $(\Sigma n): R D i=(n i / \Sigma n) \times 100$. Species Frequency $(\mathrm{Fi})$ is the chance of finding species $i$ in the observed sample plot/plot:

$$
F i=p i / \Sigma p,
$$

Where, Fi is the frequency of species i, pi is the number of sample plots where the species $i$ is found, and $\Sigma p$ is the total number of plots/ plots observed.

Relative Frequency of Species (RFi) is the ratio between the frequency of species $\mathrm{i}(\mathrm{Fi})$ and the number of frequencies for all $\operatorname{species}(\Sigma F)$ :

$$
R F i=(F i / \Sigma F) \times 100
$$

Species Closure $(\mathrm{Ci})$ is the area of closure of species $\mathrm{i}$ in a unit area: $C i=\Sigma B A / A$.

Where, $\mathrm{BA}=\mathrm{BHDBH} 2 / 4\left(\right.$ in $\left.\mathrm{cm}^{2}\right), \pi(3.1416)$ is a constant and $\mathrm{DBH}$ is the tree diameter of type $\mathrm{i}, \mathrm{A}$ is the total area of the sampling area (total plot area/plot). $\mathrm{DBH}=\mathrm{CBH} / \pi$ (in $\mathrm{cm}$ ), $\mathrm{CBH}$ is a chestlevel tree circle.

Relative Closure of Species (RCi) is a comparison between the areas of closures of species $\mathrm{i}(\mathrm{Ci})$ and the total area of cover for all $\operatorname{species}(\Sigma C i)$ :

$$
R C i=(C i / \Sigma C i) \times 100
$$

Important Value Type (IVi) is the number of species relative density values (RDi), species relative frequency (RFi) and relative closure of species (RCi).

$$
I V i=R D i+R F i+R C i
$$

Diversity Index: $H^{\prime}=-\Sigma n i / N \ln n i / N$

Where: $\mathrm{H}$ '= Shannon-Wienner diversity index; ni = number of individuals of a type $\mathrm{i} ; \mathrm{N}=$ total number of individuals of all types.

\section{Community and institutional factor analysis}

To see the factors of social conditions and community participation, the multivariable statistical analysis was used based on the Principal Component Analysis.

\section{Results and discussion}

\section{Mangrove plant species diversity}

Mangrove vegetation describes a variety of tropical coastal communities dominated by several species of typical trees or bushes that have the ability to grow in salty waters. Mangrove forest vegetation generally consists of evergreen plants from several families. According to Purnobasuki, ${ }^{9}$ mangrove forests are forest vegetation that grows in coastal areas and around river estuaries (aside from coastal forest formations) which are always or regularly flooded by seawater and affected by tides. Mangrove forest vegetation is characterized by mangrove plants (Rhizophora sp.), Fire-fire (Avicenia spp.), Prepat (Sonnerateria spp.), and tanjang (Bruguiera spp.). Based on the results of research conducted in Rangsang sub-district, mangrove vegetation species found included seven species from three families, namely Avicenniaceae family (Avicennia alba and Avicennia marina), Rhizophoraceae family (Rhizophora mucronata, Rhizophora apiculata, Rhizophora stylosa, and Bruguiera gymnorrhiza), and family Sonneratiaceae (Sonneratia alba).

\section{Mangrove vegetation composition and structure}

\section{a. Tree level}

In this study the highest importance of species (IVi) at each station was Avicennia marina $(164,749)$ at station I, Avicennia alba $(166,878)$ at station II, Avicennia marina $(110,054)$ at station III, Avicennia marina $(117,263)$ at station V, Avicennia marina VI type station $(177,621)$, Sonneratia alba $(61,437)$ at station VII, and at station VIII type Sonneratia alba $(103,079)$. To determine the state of control of vegetation species in a plant community in its habitat, an Important Value Index (IVI) is used. The higher the INP values of a species, the greater the role of the species in the community. In general, the tree level is dominated by the genus Avicennia spp. and Soneratia spp. According to Bengen ${ }^{17}$ the area closest to the sea, with a rather sandy substrate, is often overgrown by Avicenia spp. In this zone usually associate Sonneratia spp, which is dominantly grown in deep mud. Arief ${ }^{18}$ stated that Avicennia spp. many were found associated with Sonneratia spp.

\section{b. Pole level}

From the results of vegetation analysis at the station I the most important value of species (IVi) is Rhizophora mucronata $(70,586)$. The high importance of the type at the station I am influenced by the value relative density of species $(37,143)$ and high relative frequency value $(26,667)$. Where there is a station I having an important value type (IVi) which is almost the same size or there is no mangrove type that is too dominant. The same thing also happened at station III, where the highest value of type (IVi) was the highest type of mangrove Rhizophora mucronata $(72,498)$ and not too dominating. 
This can be seen from the difference in the importance of species (IVi) with other species not much different.

For this the more heterogeneous types in a community, the role will be increasingly divided and the magnitude of the important value index will be more varied. But on the contrary, the more homogeneous types in the community the role of the type will be more focused on several types, maybe even only on one type if the plant community forms a consortium. It is very different at station II, where the Rhizophora mucronata type is very dominant with an important value of 118,501 . Types that obtain high INP mean having a cumulative value of control that is greater and more controlling their habitat. This type will be superior in utilizing resources or abler to adapt to the local environment. Rhizophora mucronata type also dominates at station VII with an important value of 78.51

At station IV, the dominant mangrove species is Rhizophora stylosa $(111,686)$. While at stations V, VI and VIII the highest value of the highest species in Avicennia marina species with consecutive values 90,$884 ; 88,470 ; 60,824$. The high importance of this type is caused by most of the high relative density values of species at each observation station. In assessing vegetation, population density is often a feature of the population that first gets attention. The influence of a population is that communities and ecosystems are not only dependent on the species of the organizations involved but depend also on population numbers or density (Odum, 1993).

\section{c. Stake level}

From the results of the calculation of the important value of type (IVi) the highest at each station is Rhizophora mucronata $(78,437)$ at station I, Rhizophora mucronata $(163,693)$ at station II, Sonneratia alba $(63,751)$ at station III, Rhizophora stylosa $(107,205)$ at station IV, Rhizophora apiculata $(70,997)$ at station V, Avicennia marina $(89,771)$ at station VI, at station VII type Rhizophora stylosa $(67,306)$ and at station VIII type Avicennia alba $(62,021)$.

At the sapling level dominated by Rhizophora spp species. This can be seen from the important value of species (IVi) and the presence of this species in almost every observation station except at station III of the genus Sonneratia spp., and stations VI and VIII of the genus Avicennia spp. These three species are major mangrove plants that usually dominate mangrove areas. The dominance of Rhizophora spp. due to the muddy and slightly sandy substrate. According to Kusmana Rhizophora stylosa grows in diverse habitats in tidal areas: mud, sand, and rock, while Rhizophora mucronata likes areas that are more tolerant with harder substrates and sand.

\section{d. Semai level}

From the vegetation analysis, the seedling level which has a high importance (IVi) at each station is Rhizophora mucronata $(120,170)$ at station I, Rhizophora mucronata $(165,057)$ at station II, Sonneratia alba $(86,366)$ at station III, Rhizophora stylosa $(154,339)$ at station IV, Avicennia marina (68.29) at station V, Rhizophora mucronata $(97,173)$ at station VI, Rhizophora mucronata $(65,420)$ at station VII, and Rhizophora stylosa $(77,436)$ at station VIII.

\section{Mangrove vegetation diversity}

Species diversity index is a unique characteristic and level of community in organisms expressed through community structures. Diversity index is a vegetation parameter which is very useful to compare various community growths, especially to study the influence of environmental or abiotic factors on the community or to determine the state of succession or stability of the community (Fachrul, 2007). The diversity index value $\left(\mathrm{H}^{\prime}\right)$ of mangrove vegetation in Rangsang sub-district at each station ranged from 0.91 to 1.69 . It can be observed that the highest diversity index value at station VIII and the lowest diversity index value at station IV. The high value of the diversity index at station VIII because the number of mangrove species found was the most compared to the number of species found in other stations. While the low diversity index value at station IV due to mangrove species found only 3 types. Overall the value of the index is almost the same at each observation station. Based on the criteria raised by Shannon-Wiener in Fachrul (2007) that in general the value of the mangrove vegetation diversity index in Rangsang sub-district is abundant with a value of $H^{\prime} 1 \leq H^{\prime} \leq 3$.

\section{Mangrove vegetation environmental parameters}

In this study, observations of environmental parameters measured in Rangsang sub-district include soil texture, soil $\mathrm{pH}$, temperature, salinity and organic matter. Analysis of Community Participation Factors. From the results of factor analysis using SPSS 15 obtained three factors of community participation in mangrove forest management, namely:

\section{a. Management factors}

The management factor consists of 9 (nine) variables which can be explained as follows:

i. The community becomes a partner in managing mangrove forests

ii. People participate in managing mangrove forests

iii. Decision making in the management of mangrove forests

iv. The community processes in managing mangrove forests

v. Management (planning, implementing, monitoring) in managing mangrove forests

vi. Institutional and administrative community participation in the management of mangrove forests

vii. Management methods in mangrove forest management

viii. Objectives in mangrove forest management

ix. Communities as managers/implementers/processors in the management of mangrove forests. Interpretation results can explain $46.309 \%$ of total uniformity, meaning that the decision of community participation in mangrove forest management is $46.309 \%$ determined by management factors.

\section{b. Knowledge factor}

The knowledge factor consists of 4 (four) variables that can be described as follows:

i. The level of community education in the management of mangrove forests

ii. Benefits of mangrove forests obtained for the community

iii. Support / facilities provided by the community in managing mangrove forests

iv. Systems in managing mangrove forests. From the interpretation results can explain $19.286 \%$ of total uniformity, meaning that the decision of community participation in mangrove forest 
management is $19.286 \%$ determined by knowledge factors.

\section{c. Attitude factor}

Attitude factors consist of 2 (two) variables that can be described as follows:

i. Violations that occur in the management of mangrove forests

ii. Natural regeneration in the management of mangrove forests From the interpretation results can explain $9,178 \%$ of total uniformity, meaning that the decision of community participation in mangrove forest management $9,178 \%$ is determined by the attitude factor.

\section{Mangrove forest management in Rangsang District}

Mangrove ecosystem management is based on three main stages, namely the existing issues. These issues are ecological issues, economic issues, institutions and legal instruments and strategies and implementation of plans. In this case, the strategy and implementation of the plan are within the framework of mangrove management and conservation, having two main concepts defined. The two concepts basically provide legitimacy and understanding that mangroves really need management and protection in order to remain sustainable. Both concepts are the protection of mangrove forests and rehabilitation of mangrove forests. One way that can be done in order to protect the existence of mangrove forests is to designate a mangrove forest area to be used as a conservation area, and as a form of green belt along the coast and river banks. While rehabilitation efforts are carried out to restore the condition of mangrove ecosystems that have been damaged so that the mangrove ecosystem can re-run its functions properly.

Mangrove forest management in Rangsang sub-district is carried out by community self-help groups, namely Mangrove Forest Rehabilitation Group "Bentar Indah". The Mangrove Hut Rehabilitation Group "Bentar Indah" was the driving force of the drive group which was formed on August 14, 2004. The form of management carried out by this Group was to rehabilitate mangroves in the Curah Sawo Village in Rangsang District. Activities that have been carried out include:

a) In October 2004 the planting area of $7 \mathrm{Ha}$ was carried out, with a number of 17,500 seeds with a spacing of $2 \times 2 \mathrm{~m}$;

b) In the following year 2005 planted an area of 16 ha with a number of 40,000 seedlings with a spacing of $2 \times 2 \mathrm{~m}$; (3) in 2006 planted an area of 15 ha with a number of 37,500 stems with a spacing of $2 \times 2 \mathrm{~m}$;

c) Activities in 2007 planted a mixture of 12 ha of Avicennia marina, Rhizophora mucronata and Sonneratia alba species;

d) In 2008 carrying out planting activities in a random or patchy manner. The mangrove planting process is usually carried out during the rainy season, due to the influence of the humidity temperature factor.

For the planting process Avicennia, Rhizophora and Sonneratia sp. almost the same, namely as follows:

A. The first step is the procurement of seeds that are ready in a poly bag and ready to be planted and prepare for making enough sticks made of wood or bamboo measuring $\pm 30 \mathrm{~cm}$ long and raffia to taste.
B. The second step is to make a puddle in the ground with a diameter of $15-20 \mathrm{~cm}$ and a depth of $\pm 20-30 \mathrm{~cm}$.

C. The third step is the inclusion of mangrove seeds that are ready in the poly bag into the prepared soil.

D. The next step is to isolate the buffer on the sides of the mangrove seedlings with sticks made of wood or bamboo, and then the upper end is propped against the stems of the mangrove seedlings and tied to the raffia. While the

E. Other end, which is under it, is plugged into the ground with sufficient depth.

The process of planting mangrove seedlings as above has been applied to people in Rangsang sub-district, especially the people of Teluk Samak, Tanjung Gemuk, Rangsang, and Bantar Village. But there is one type of mangrove plantations with mangrove seeds in bamboo. This type of planting has only been done by the community of Samak and Gemuk Village, the purpose of the inclusion of mangrove seeds in the bamboo that has been perforated is to prevent the breaking of the stem of the mangrove seedlings due to waves or eaten by animals. Way planting mangrove seeds with planting patterns in bamboo are as follows:

i. The availability of seeds that are already in the poly bag and ready to be planted.

ii. Preparation for making bamboo as a planting aid with a length of $80-100 \mathrm{~cm}$ in diameter $5-8 \mathrm{~cm}$ and the center part is perforated.

iii. Making a wooden stick with a width of $5 \mathrm{~cm}$ and a length of 80 $100 \mathrm{~cm}$.

iv. Make a planting hole with $10-15 \mathrm{~cm}$ in the coastal land that will be planted.

v. Seedlings of the polybag are removed and planted in ground holes that have been made, and then plugged in the bamboo that has been perforated, so that the seeds of the mangrove plant are inside the bamboo.

\section{Sticks are plugged around plants and tied with raffia}

In addition to conducting rehabilitation, the Rangsang subdistrict community also carried out maintenance and supervision. Maintenance and supervision aimed at mangroves in the form of observations on the condition of plants in mangrove forest land, in order to maintain whether the mangroves are still in good condition or not, especially new plants from the rehabilitation susceptible to pest disturbances. Based on field observations, several mangrove rehabilitation areas were attacked by trips which attached to mangrove stems which caused the growth of mangrove plants to be slow due to the absence of new roots which function to absorb nutrients and protect mangroves from the waves. According to some practitioners, if the plant is overgrown with the barnacle, an effective step to save the plant is by manually removing the barnacle by scraping it with a knife slowly so as not to damage the mangrove bark. ${ }^{19}$

For the maintenance of new plants, the action taken by the Rangsang sub-district community is to make a buffer on the stem of a new mangrove plant with a stick made of wood or bamboo that is attached to the stem of a mangrove plant and plugged into the substrate where the plant grows. In addition, thinning was carried out on mangroves which reached \pm 1 meter in height, which meant 
that other mangroves would get sufficient energy for photosynthesis which had an impact on subsequent breeding.

While the supervision carried out on mangrove forest users is still limited to emotional approach, namely by reprimanding and warning to parties who arbitrarily cut down trees and those who seek rotus worms in the mangrove forest area. Supervision is carried out by the entire coastal community in Kecamatan Rangsang. If the community sees the violation, the community can immediately report to one of the group's administrators and then the group administrator will give a warning or confiscation of the tools used in felling trees or wormfinding devices.

\section{Development of community participation in mangrove forest management}

Management of mangrove forest ecosystems with community involvement is a dynamic and sustainable process that brings together various interests (government and society), science and management, and sectoral interests and the general public. ${ }^{20}$ Community-based management here is that the use of the main resources in the community and must be the resource management actor. ${ }^{21}$ The involvement of communities is needed for the sake of sustainable management of resources, and in general different groups of people will also differ in their importance to those resources..$^{22}$ Resource management will not succeed without including all parties who have interests.

A community-based development can be formed if there is a group collaborating because they are aware that they cannot work on their own tasks and cannot achieve their goals individually either because of the nature of the task or the goal itself or because of limited resources. ${ }^{22}$ Togetherness and similarity inattention, caring, usually makes the community unite. If togetherness is institutionalized and creates loyalty, mutual trust, the creation of rules of the game, then this is the basis of the formation of a community base. So that the right strategy needs to be done to deal with issues that affect the coastal environment through active participation and tangible forms of the coastal community itself. ${ }^{23}$ The participation of the community is important in the effort to manage community-based mangrove forests. Many management programs and activities are less successful due to the implementation of the program failed to involve community participation from the beginning of the program.

The development of community participation in mangrove management at its base is an effort to involve the community so that they are consciously and actively involved in mangrove management activities. Engagement can be realized if a person feels that his participation can provide benefits to him, where the benefits are not only in the form of mangrove forest functions that are felt in the short term. Based on the analysis of participation and management of mangrove forests in Rangsang District, there are several factors that need to be considered in the effort to develop community participation in the management of mangrove forests.

\section{Management factors}

As we all know, the implementation of mangrove forest management that has occurred in recent years has been carried out on orders from above. Like a habit in any program whose name the plan always comes from above; while subordinates (community) are the spearhead of program implementers only just carry out orders or with popular terms with a top-down approach. ${ }^{22}$ The implementation of this kind of program is of course not empowering the potential of the community, even though ideally the position of the community as a government partner in implementing the program. The community must play an active role in the management of the mangrove forest. The community as a planning, implementation, evaluation of its success and sustainable use are all entrusted to the community, while the government is only a provider of funds, controllers, and facilitators of various related activities. According to Raharjo, ${ }^{24}$ communitybased management means the direct involvement of the community in managing mangrove forests in an area.

Managing means people participate in thinking about, formulating, planning, implementing, evaluating and monitoring something that is their need. In order to run a mangrove forest management program by involving the active participation of local communities, it is necessary to establish a Community Self-Help Group (KSM). In Rangsang sub-district it already has a self-help group (KSM) which is the rehabilitation group of the mangrove forest "Bentar Indah". The involvement of the community institutionally and administratively in the Group is very important because through the CBOs can be implemented a mangrove forest rehabilitation program, dissemination of information per the legislation, dissemination of information on fish farming techniques, as well as facilitate moving the community to participate actively in mangrove forest conservation activities.

Information on planning for mangrove forest rehabilitation and management (location, area, objectives, targets, components involved, implementation, etc.) needs to be conveyed to the community through village officials or through KSMs so that there is a clear information hold for the community. This is important so as not to cause anxiety for the community, and is even expected to further encourage active participation of the community in the management of mangrove forests. For example, the community or CBOs do mangrove planting activities, before planting the group must have knowledge of mangrove rehabilitation techniques such as growing conditions, ideal conditions for growth, fruit selection and ways to plant mangroves. Armed with this information later the group plans to plant activities, such as location and time of planting and those involved in planting. The implementation of mangrove planting activities is coordinated by groups involving a lot of people, including women and school children. Before planting, the group explained to the participants about the methods of planting. In this planting, the group provided mangrove fruit, stalk, lunch and T-shirt. From the first stage of planting, then proceed to the second, third stage and so on. In some planting activities, collaboration is needed between local governments, NGOs, and community groups. Cooperation is needed to obtain funding assistance and group capacity building. ${ }^{25}$

During the implementation of activities, community groups conduct regular and periodic monitoring and evaluation of ongoing activities. Monitoring is carried out to monitor problems that arise during the activities at each stage and find alternative solutions. Not infrequently from the results of monitoring forces the group to adjust or change the action plans at certain stages in accordance with the conditions of the field. All input and observations from monitoring are then evaluated. Evaluation is done to find out all the weaknesses and strengths of the activities carried out for future improvement. In addition, evaluation is also carried out to assess and match the goals that have been set and even adjust the objectives in the midst of the implementation of the activities.

Development of community participation in mangrove forest management requires a flexible, patient and time-consuming approach. Building people's understanding and belief in the importance of mangrove forest management is very time consuming 
and can slow down the measurement of progress in the rehabilitation of mangrove forests. A Bengen ${ }^{26}$ mention the problem of managing mangrove forests sustainably is how to combine ecological interests (forest conservation mangrove) with the socio-economic interests of the community around the mangrove forest. But the above is comparable to long-term results because it can build a strong sense of ownership and community commitment which is a guarantee of the sustainability of mangrove forest rehabilitation and management. Efforts to have meaningful and sustainable community involvement in the management and rehabilitation of coastal resources cannot be achieved through only one program that is limited by scope and area and limited frameworks and deadlines. Thus, the established strategy must be able to overcome the socio-economic problems of the community in addition to the goal of conserving mangrove forests.

\section{Knowledge factor}

In an effort to develop community participation that also needs to be considered is the knowledge factor. $\mathrm{Mazda}^{23}$ said that the development of knowledge factors can be carried out through educational activities. Educational activities are an effort to raise public awareness about the importance of mangrove forests, their preservation and re-rehabilitation, and the importance of community groups to deal with their problems. Education is carried out more non-formal through meetings/discussions. In this activity, it is hoped that community support/facilities will invite various community representatives such as formal and informal community leaders, teachers, RT/RW leaders, traders, fish farmers and fishermen. For example, at the meeting identified various problems faced by the community, especially regarding the growth and progress of the village, as well as aquaculture and fisheries activities in general. The topics discussed were analyzed by making comparisons between the previous conditions and the present, and discussing why these changes occurred. From this meeting, it was described by participants, various problems faced, such as abrasion, shrimp culture failure, decreased the productivity of ponds and so on. Exposure to this problem was discussed to find various causes including due to damage to the mangrove forest along the coast of the village. Then try to find and analyze several alternative solutions. This process continues until the acceptance of the idea that mangrove management will provide sustainable benefits for communities such as aquaculture and fisheries and can prevent abrasion that has damaged community ponds.

After the community is motivated to manage the mangrove forest area, the next stage is to provide technical and management training. The purpose of the training is to provide knowledge and skills related to the management of mangrove forest areas. The training material that must be delivered is:

A. Management of sustainable management of mangrove forest areas

B. Technique for rehabilitation, care and protection of mangrove plants

C. Fish and non-fish cultivation techniques in mangrove areas

D. Fishing / non-fish fishing techniques in mangrove areas

The training method is packaged in the form of practice in the location of the mangrove area. To give confidence to the community, after the skills training, the government needs to provide a pilot package of efforts to utilize mangrove forests. In the implementation of these activities can also involve Non-Governmental Organizations (NGOs) with village officials, community leaders, and others.

\section{Attitude factor}

Until now, efforts to maintain the sustainability of the functions and benefits of mangrove forests or brackish forest areas by local governments still appear not running properly. There are still many conflicts of interest that are not in accordance with the designation of mangrove areas. The people's view of the mangrove forest area is still more dominant in economic or money-making matters. Therefore, coastal communities as a whole need to understand that the mangrove forests that they will rehabilitate will become the property of the community and for the community, especially those in coastal areas. Thus all the processes of rehabilitation or reforestation of mangrove forests, which starts with the process of planting, care, and planting, are carried out by the community. Through this mechanism, the community does not feel they are considered "coolies", but rather own the mangrove forest, because they feel they are planning to plant and others. ${ }^{21}$

The community feels that they have a stake in the effort to rehabilitate the mangrove forest, so that their status will change, which is not as a "coolie" anymore but rather have it. ${ }^{27}$ From here it will be illustrated if there were a group of people who were not members of the community who participated in planting the mangrove forest, they just wanted to cut a mangrove plant, so they would certainly be busy preventing or reminding them that they were cutting trees without permission. To prevent this, a written rule is needed, whereby the regulation contains sanctions made by the community according to the social and economic conditions of the Rangsang community. With the right policies and regulations, it is still possible to maintain the sustainability of mangroves, not only to pay attention but also need real action in preserving. The use of mangroves must be as wise as possible without having to damage, but we can continue to benefit from it. ${ }^{28-51}$

\section{Conclusion}

1. Mangrove vegetation consists of seven species from three families, namely Avicenniaceae family (Avicennia alba and Avicennia marina), family Rhizophoraceae (Rhizophora mucronata, Rhizophora apiculata, Rhizophora stylosa, and Bruguiera gymnorrhiza), and family Sonneratiaceae (Sonneratia alba). The value of mangrove vegetation diversity index $(\mathrm{H}$ ') ranged from 0.91 to 1.69 . The quality condition of mangrove habitat is characterized by the texture of clay sand, sandy loam and sandy clay; Soil $\mathrm{pH}$ 6.6-7.1; temperature $29-31^{\circ} \mathrm{C}$; salinity $27-31 \mathrm{ppt}$; and soil organic matter content of $1.09-7.65 \% \mathrm{C}$.

2. Three factors for decision making in community participation in mangrove forest management are management factors, knowledge factors and attitude factors.

3. Mangrove forest management by the community includes rehabilitation, maintenance and supervision. In an effort to manage community-based mangrove forests active community participation is required by taking into account management factors, knowledge factors and attitude factors.

\section{Acknowledgments}

None.

\section{Conflicts of interest}

Author declares there is no conflicts of interest. 


\section{References}

1. Kathiresan K. Importance of mangrove ecosystem. International $J$ Marine Science. 2012;2(10):70-89.

2. Setyawan AD. Mangrove ecosystem in Java: 1. recent status. Biodiversitas. J Biological Diversity. 2003;4(2):130-142.

3. Mishra RR, Rath B, Thatoi H. Water quality assessment of aquaculture ponds located in Bhitarkanika: mangrove ecosystem, Orissa, India. Turkish J Fisheries \& Aquatic Sciences. 2008;77:71-77.

4. Kusmana C. Management of mangrove ecosystem in indonesia. JPSL. 2011;1(2):152-157.

5. Finn M, Kangas P, Adey W. Mangrove ecosystem development in Biosphere 2. Ecological Engineering. 1999;13(1-4):173-178.

6. Kathiresan K. Importance of mangrove ecosystem. Centre of advanced study in marine biology, Annamalai University; 2006:2-500.

7. Badola R, Hussain SA. Valuing ecosystem functions: An empirical study on the storm protection function of Bhitarkanika mangrove ecosystem, India. Environmental Conservation. 2005;32(1):85-92.

8. Tingsabadh C, Pongkijvorasin S. Chapter 15 - Economic valuation of mangroves for improved usage and management in Thailand. Wetlands Ecosystems in Asia. 2004:263-281.

9. Purnobasuki H. Review of the Mangrove Forest Perspective. Surabaya: Airlangga University Press publisher; 2005.

10. Pontoh O. Peranan nelayan terhadap rehabilitasi ekosistem hutan bakau (mangrove). J Perikanan Dan Kelautan Tropis. 2011:73-79.

11. Brander LM, Wagtendonk AJ, Hussain SS, et al. Ecosystem service values for mangroves in Southeast Asia: a meta-analysis and value transfer application. Ecosystem Services. 2012;1(1):62-69.

12. Schwerdtner Máñez K, Krause G, Ring I, et al. The Gordian knot of mangrove conservation: Disentangling the role of scale, services and benefits. Global Environmental Change. 2014;28(1):120-128.

13. Silva LFF, Machado W, Filho SDL, et al. Ecosystem in se Brazil. Water, Air, \& Soil Pollution. 2003;145:67-77.

14. Field CD. Rehabilitation of mangrove ecosystems: an overview. Marine Pollution Bulletin. 1999;37(8-12):383-392.

15. Indrayanti MD, Fahrudin A, Setiobudiandi I. Penilaian Jasa Ekosistem Mangrove di Teluk Blanakan Kabupaten Subang. J Ilmu Pertanian Indonesia. 2015;20(2):91-96.

16. Kaplowitz MD. Assessing mangrove products and services at the local level: The use of focus groups and individual interviews. Landscape and Urban Planning. 2001;56(1-2):53-60.

17. Bengen DG. Sampling techniques and biophysical data analysis of coastal resources. Center for coastal and ocean resource studies. Faculty of Fisheries \& Marine Sciences, Bogor: Bogor Agricultural University; 2000 .

18. McNally CG, Uchida E, Gold AJ. The effect of a protected area on the tradeoffs between short-run and long-run benefits from mangrove ecosystems. Proc Natl Acad Sci U S A. 2011;108(34):13945-13950.

19. Arief A. Mangrove forest functions and benefits. Yogyakarta: Kanisius publisher; 2003.

20. Hilmi E, Parengrengi, Vikaliana R, et al. The carbon conservation of mangrove ecosystem applied REDD program. Regional Studies in Marine Science. 2017;16:152-161

21. Lee SY, Culén AL, Resources N, et al. Mangrove biodiversity and ecosystem function. Ecosystems. 2010;7(1):1-26.
22. Cintrón G, Schaeffer-Novelli Y. Methods for studying mangrove structure. The Mangrove Ecosystem: Research Methods. 1984:91-113.

23. Field CB, Osborn JG, Hoffman LL, et al. Mangrove biodiversity and ecosystem function. Global Ecology \& Biogeography Letters. 1998;7(1):3-14.

24. Mazda Y. The mangrove ecosystem utilizes physical processes. Global Environmental Research. 2013;17:165-172.

25. Rahardjo Y. Community base management in the indonesian coastal area Proceedings of the ICZPM Training, PKSPL IPB and the directorate general of regional secretariat of the ministry of home affairs. 1996.

26. Schaeffer-Novelli Y, Cintrón-Molero G, Soares MLG, et al. Brazilian mangroves. Aquatic Ecosystem Health \& Management. 2003;3(4):561570 .

27. Bengen DG. Technical Guidelines for the Introduction and Management of Mangrove Ecosystems. Center for Coastal and Marine Resources Studies. Bogor, Indonesia: Bogor Agricultural University; 2001.

28. Aksornkoae S. Management and conservation of mangrove management in Southeast Asia: policies, management strategies and case studies. In: Chua Tia Eng, Daniel Patty, editors. ASEAN-USCRM Project; 1989.

29. Aliadi A, Widjarjo B, Gunawan G, et al. Community participation in forest conservation: the case in ujung kulon-west java; tenganan-bali; and krui-lampung. WALHI and FoE Indonesia; 1994.

30. Barkey R. South Sulawesi mangroves (structure, function and rate of degradation). Proceedings of the seminar on integration between conservation and wetland use in South Sulawesi. LIPI-Local Government of South Sulawesi; 1990

31. Bengen DG. Synopsis of Coastal Ecosystems and Resources. Center for Coastal and Marine Resources Studies. Bogor, Indonesia: Bogor Agricultural University; 2000.

32. Butar-butar M. Development of management of coastal resources in regions. Proceedings of the 1 st National conference on the management of Indonesian coastal and ocean resources, IPB. 1998.

33. Dahuri R. Integrated management of coastal and oceanic resources Jakarta: PT Pradnya Paramita; 1996.

34. English S, Wilkinson C, Baker V. Manual survey for tropical marine resources. ASEAN-Australia marine science project living coastal resources; $1986.390 \mathrm{p}$

35. Erftemeijer PLA, Bualung A. Participation of local communities in mangrove forest rehabilitation in pattani bay. Thailand: Learning from Successes and Failures; 1998

36. Harahab N. Economic valuation of mangrove forest ecosystems and their application in coastal area planning. UB Fisheries Faculty; 2008.

37. Hutchings P, Saenger P. Ecology of mangrove. Australia: University of Queensland Press; 1987.

38. Kusmana C. Vegetation survey method. Bogor Agricultural University Publisher; 1997.

39. Murdiyanto B. Getting to know, maintain and preserve mangrove forest ecosystems. Jakarta: The Directorate General of Capture of the Ministry of Maritime Affairs and Fisheries; 2003.

40. Noor YR, Suryadiputa IN, Khazali M. Guide to Introduction of Mangroves in Indonesia. Bogor: Wetlands International-Indonesia Program; 1999

41. Nugroho BF, Dwi Joko Priyono J, Tetalepta NL, et al. Management of coastal areas for sustainable use of Natural resources. Bogor: Bogor Agricultural University Science Philosophy; 2001. 
42. Nybakken JW. Marine biology: an ecological approach. In: Mohammad Eidman H, Koesbiono DG Bengen, et al. editors. Jakarta: Publisher PT, Gramedia Main Library; 1988.

43. Pariwono JI. The Dynamics of Coastal Waters in Mangrove Forest Areas Collection of integrated and sustainable paper for mangrove ecosystem conservation and development training. PLPL - LP UNIBRAW; 1996

44. Pramudji. Dynamics of Mangrove Forest Areas in Kotania Bay Coastal Area, West Seram. Oseana. Jakarta: Indonesian Institute of Sciences; 2001.

45. Romimohtarto K, Juwana S. Marine Biology. LIPI. Jakarta: Oceanographic Research and Development Center; 1999.

46. Saenger P, Hegerl EJ, Davie JDS. Global Status of Mangrove Ecosystems. IUNC Commission on Ecology. 1983. 88 p.
47. Second International Conference on Wetlands and Development, Dakar Senegal.

48. Soeroyo. Mangrove Growth and Problems. Scientific bulletin inaugurates jungle ambassadors. Jogjakarta: Faculty of Forestry UGM; 1993.

49. Sunoto. Coastal community system and development strategy. Integrated Coastal Area Planning and Management Training, class I. Bogor: PKSPL-IPB and DG Bangda Depdagri; 1997.

50. Supriharyono. Conservation of biological resources ecosystems in coastal and tropical seas. Yogyakarta: Learning Library; 2007.

51. Tomascik JW, AJ Mah, Nontji A, et al. The ecology of the Indonesian Seas. Canada: Periplus Edition; 1997. 